KORONAVÍRUS - GYORSJELENTÉSEK / REPORTS ON THE COVID-19 PANDEMIC IN HUNGARY

\title{
A koronavírus-járvány jelenlegi és várható egészségkockázatainak területi különbségei Magyarországon
}

\section{Present and Future Health Risks and Their Regional Differences in Hungary Regarding COVID-19 Pandemic}

\author{
KOVÁCS SÁNDOR ZSOLT, UZZOLI ANNAMÁRIA
}

\begin{abstract}
KOVÁcS Sándor Zsolt: tudományos segédmunkatárs, Közgazdaság- és Regionális Tudományi Kutatóközpont, Regionális Kutatások Intézete; 7621 Pécs, Papnövelde u. 22.; kovacs.sandor@krtk.mta.hu; https://orcid.org/0000-0001-6612-6296

UZZoLI Annamária: tudományos főmunkatárs, Közgazdaság- és Regionális Tudományi Kutatóközpont, Regionális Kutatások Intézete; 1097 Budapest, Tóth Kálmán u. 4.; uzzoli.annamaria@krtk.mta.hu; https://orcid.org/0000-0002-0484-1451
\end{abstract}

KULCSSZAVAK: egészségkockázat; egészségegyenlőtlenség; területi különbségek; komplex index; COVID-19

Sándor Zsolt KOVÁCS: junior research fellow, Institute for Regional Studies, Centre for Economic and Regional Studies; Papnövelde u. 22., H-7621 Pécs, Hungary; kovacs.sandor@krtk.mta.hu; https://orcid.org/0000-0001-6612-6296

Annamária UZZOLI: senior research fellow, Institute for Regional Studies, Centre for Economic and Regional Studies; Tóth Kálmán u. 4., H-1097 Budapest, Hungary; uzzoli.annamaria@krtk.mta.hu; https://orcid.org/0000-0002-0484-1451

KEYWORDS: health risk; health inequality; regional differences; complex index; COVID-19

A járvány jelenlegi „akut” és várható „krónikus” egészséghatásai

A COVID-19 új koronavírus-betegség okozta világjárvány újszerü társadalmi és gazdasági helyzetet teremtett a világ országai számára. A hatások az élet minden területén érzékelhetők, a hosszú távú következmények egyelőre kiszámíthatatlanok. Tény, hogy az új kihívások az eddigiektől eltérő megoldásokat követelnek meg, a gyors válaszreakciók, valamint az igazságosság, méltányosság elvén alapuló szakpolitikai beavatkozások eredményessége nagymértékben függ az adott ország helyzetfelismerő és stratégiaalkotó képességétől.

A koronavírus-járvány közvetlen hatásai először az egészségügyben jelentkeznek: a fertőzöttek szürése és gyógyítása, a súlyos esetek kórházi ellátása, a ha-

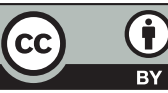


lálozások számának csökkentése, az adekvát egészségügyi szolgáltatások és ellátásfajták megfelelő kapacitással való fenntartása, az egészségügyi szakdolgozók egészségvédelme súlyos terheket ró az ellátórendszerre, a készletgazdálkodásra és az ellátásszervezésre.

Az „akut” egészségügyi problémák a járványügyi veszélyhelyzet idején jelentkeznek, amikor a tömeges számú fertőzött ellátása az egészségügyi ellátórendszer túlterheltségével és kapacitáshiányokkal járhat együtt. Ugyanakkor a „krónikus” problémák megjelenése közép- és hosszútávon várható, hisz a járvány idején számos feltétel akadályozza a nem koronavírus-fertőzöttek számára az egészségügyi ellátáshoz való hozzáférést, ami egészségromláshoz és/vagy elkerülhető halálozáshoz vezethet.

Magyarország a főbb egészségmutatók alapján (születéskor várható átlagos élettartam, keringési rendszeri és daganatos halálozási arányszám stb.) a világ fejlett országai között a sereghajtók közé tartozik (Uzzoli 2019). A magyar népesség nemzetközi viszonylatban kedvezőtlen egészségi állapota miatt járvány idején is különösen fontos a népegészségügyi kihívások kezelése és megoldása. Ennek egyik lehetséges eszköze a járvány által közvetlenül, illetve áttételesen érintett sérülékeny társadalmi csoportok és területi elhelyezkedésük azonosítása. Elemzésünkben a hazai egészségi állapot és az egészségügyi ellátórendszer területi különbségein keresztül értelmezzük a koronavírus-járvány potenciális veszélyeit és egészségkockázatait. ${ }^{1}$

\section{Egészségi állapot - térbeliség - elérhetőség}

A hazai egészségi állapot területi különbségeinek mérése a funkcionális távolság gazdasági elemzésekben alkalmazott formulájának átstrukturálásával történt meg (Alessandrini et al. 2009; Kovács 2018), amely jelen esetben az egészségügyi intézmények elérhetőségén túl figyelembe veszi a vizsgált területegység (település, járás) társadalmi, gazdasági, intézményi jellemzőit és a helyi népesség egészségi állapotának fó mutatóit az alábbiak szerint: ${ }^{2}$

- Járóbeteg-szakrendelők elérhetősége: az egészségügyi alapellátás (pl. háziorvosi ellátás) minden településen legalább helyettesítéssel elérheto", azonban a krónikus betegségek gondozása, a szürés, a speciális szakellátás és az egynapos sebészetek a szakrendelőkben találhatók. Ezek területi ellátási kötelezettsége a járásokra terjed ki, azonban nem minden járásban müködik szakrendelő. A lakóhely és a szakrendelő közötti távolság meghatározó a szakellátás igénybevételében, a szakellátáshoz való hozzáférésben, így vizsgálatunkban felhasználtuk az egyes települések legközelebbi járóbetegszakrendelőtől való, közúton, kilométerben meghatározott távolságát.

- A települések társadalmi helyzetét több mutatószám együttes alkalmazásával elemeztük. A korosztály nagyobb kitettsége okán felhasználtuk a te- 
lepülések 65 évnél idősebb lakosságának 1000 före vetített értékét, a születéskor várható átlagos élettartamot, a nyers és okspecifikus halálozási arányszámot, amelyek a népesség egészségi állapotának közvetlen információhordozói. Ez utóbbi esetében a keringési rendszeri és daganatos megbetegedések 1000 főre számított települési értékét vettük alapul, mert e két krónikus betegség (általában mindenkinek kiemelt kockázat) a koronavírus-járvány idején.

- A települések közti gazdasági különbségeket is kezeli a jelen esetben alkalmazott komplex mutatószám, így a vállalkozások és a munkaerő ágazati megoszlása került be az elemzésbe, valamint a település internet ellátottsága, mert az internethez való hozzáférés szerepe különösen megnőtt a járvány idején a home office vagy a home learning különböző formái miatt.

- A betöltetlen és tartósan (legalább hat hónapja) betöltetlen háziorvosi praxisokban helyettesítéssel történik a betegek ellátása, de ez legtöbbször a rendelési idő csökkenésével, az elérhetőség időbeli és fizikai romlásával és az ellátáshoz való hozzáférés akadályaival jár együtt. Éppen ezért települési dummy változót alkalmaztunk a komplex indikátor kialakításakor, amelynek az értéke 1, ha a településen levő háziorvosi praxisoknak legalább 20\%-a betöltetlen, és értéke 0 , ha ez az arány kisebb 20\%-nál. (Lásd a Függelék módszertani leírását.)

Az egészségi állapot társadalmi-területi különbségeit számos (társadalmi, gazdasági, szociokulturális) tényező befolyásolja, a kiváltó okok egy része az egészségügyi ellátáshoz való hozzáférés esélyeihez kötődik (Dahlgren, Whitehead 1991). A hozzáférés esélyei/esélytelenségei pedig részben összefüggenek a megfelelő mennyiségű és minőségű egészségügyi kapacitások rendelkezésre állásától térben és időben (meglévő szolgáltatások), valamint az egészségügyi szolgáltatások elérhetőségétől (időbeli és fizikai távolságok) (McIntyre et al. 2009).

\section{Koronavírus-járvány Magyarországon - Számokban}

Magyarországon 2020. március 4-én regisztrálták az első két új koronavírus-megbetegedést, majd a kormány március 11-én veszélyhelyzetet hirdetett meg az országban. 2020. április 23-ig (jelen kézirat leadási időpontjáig) összesen 2284 igazolt fertőzött esetet regisztráltak: közülük 236 fó elhunyt, 1655 fő volt az aktív esetek száma, és összesen 390 fö gyógyult meg (1. táblázat).

A napi új esetszámok folyamatos növekedésében 2020. április 23-ig, a járvány terjedésének sebességével összefüggésben három jellemző szakasz volt elkülöníthető (1. ábra):

- Egyedi esetek szakasza (2020. 03. 04. - 2020. 03. 20.): ebben az időszakban az összes eset száma 100 fő alatt volt, a napi esetszám az első két hétben 10 fö alatt volt, majd 10-15 fö között mozgott. 2020. 03. 20-án 
1. táblázat: A koronavírus-járvány néhány jellemzője Magyarországon, 2020. 04. 23. Some data of COVID-19 pandemic in Hungary, 23. 04. 2020.

\begin{tabular}{lc}
\hline Jellemző & 2020.04 .23$. \\
\hline Összes eset (fö) & 2284 \\
Összes haláleset (fö) & 236 \\
Összes gyógyult beteg (fó) & 390 \\
Aktív betegek száma (fó) & 1655 \\
Hatósági házi karanténban lévők száma (fó) & 10942 \\
Mintavétel száma (db) & 55390 \\
Összes fertőzött száma / 100 000 lakos (fó) & 24 \\
Összes haláleset száma / 100 000 lakos (fó) & 2 \\
Összes haláleset az összes fertőzött arányában (\%) & 10,3 \\
Összes mintavétel / 1 millió lakos (fő) & 5710 \\
\hline
\end{tabular}

Adatok forrása: koronavirus.gov.hu

már összesen 85 fö fertőzött volt az országban, és a napi esetszám kitartó, folyamatos növekedésnek indult.

- Csoportos megbetegedések szakasza (2020. 03. 21. - 2020. 04. 09.): ebben az időszakban átlagosan 45 fővel nőtt a napi esetszám. Legkevesebb napi új fertőzöttet 2020. 04. 06-án regisztráltak (11fö), míg a legtöbbet 2020. 04. 09-én

1. ábra: Az igazoltan COVID-19 új koronavírussal fertőzöttek napi új eseteinek száma Magyarországon (fó), 2020. 03. 04. - 2020. 04. 23. New daily cases of COVID-19 pandemic in Hungary (incidence), between 04. 03. 2020. and 23.04. 2020.

(fö)
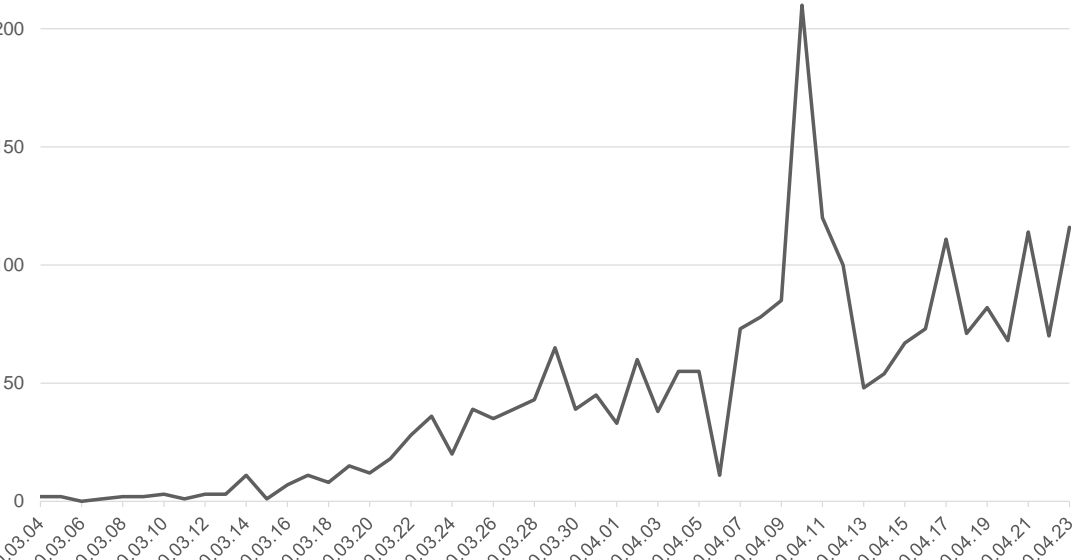
$2^{2} 2^{2} 2^{2} 2^{2} 2^{2} 2^{2} 2^{2} 2^{2} 2^{2} 2^{2} 2^{2} 2^{2} 2^{2} 2^{2} 2^{2} 2^{2} 2^{2} 2^{2} 2^{2} 2^{2} 2^{2} 2^{2} 2^{2} 2^{2} 2^{2} 2^{2}$ Adatok forrása: koronavirus.gov.hu 
(85 fö). Az időszak végére az összes fertőzött esetszám meghaladta a 900 főt az országban.

- Növekvő számú csoportos megbetegedések szakasza (2020. 04. 10-től): részben felgyorsult a járvány üteme és terjedése. Az összes esetszám már meghaladta az 1000 főt, és a napi esetszámok is már 100, illetve 200 fö felett voltak egyes napokon (például 04. 10-én és 11-én). A járvány terjedésében területi (Budapest) és intézményi gócpontok (idősek otthona) alakult ki. Az elhunytak száma 200 fölé emelkedett.

A hazai új koronavírus-járvány április 23-ig nem lépett be a tömeges fertőzések szakaszába. Az egyes napokon tapasztalt növekvő új esetszám (incidencia) egyes fővárosi, illetve néhány vidéki idősotthonban bekövetkezett nagyobb számú fertőzésből adódott.

Az első haláleset a fertőzésből következően 2020. 03. 15-én következett be az országban, de 03. 25-ig 10 fö alatt volt az összes haláleset (2. ábra). Az első igazolt megbetegedés időpontjához képest (03. 04.) az első gyógyult beteget 03. 12-én regisztrálták.

Az új koronavírus okozta halálozási arányszám 10,3\% volt az összes fertőzött arányában április közepén. Megjegyezzük, hogy a tényleges halálozási arányszám ennél az értéknél alacsonyabb lehet, ugyanis nincsenek pontos adataink a fertözöttek valós számáról, amely az igazolt esetek többszöröse is lehet az országban.

2. ábra: A koronavírus-járvány megbetegedési és halálozási jellemzői Magyarországon, 2020. 03. 04. - 2020. 04. 23.

Morbidity and mortality data of COVID-19 pandemic in Hungary, between 04. 03. 2020. and 23.04. 2020.

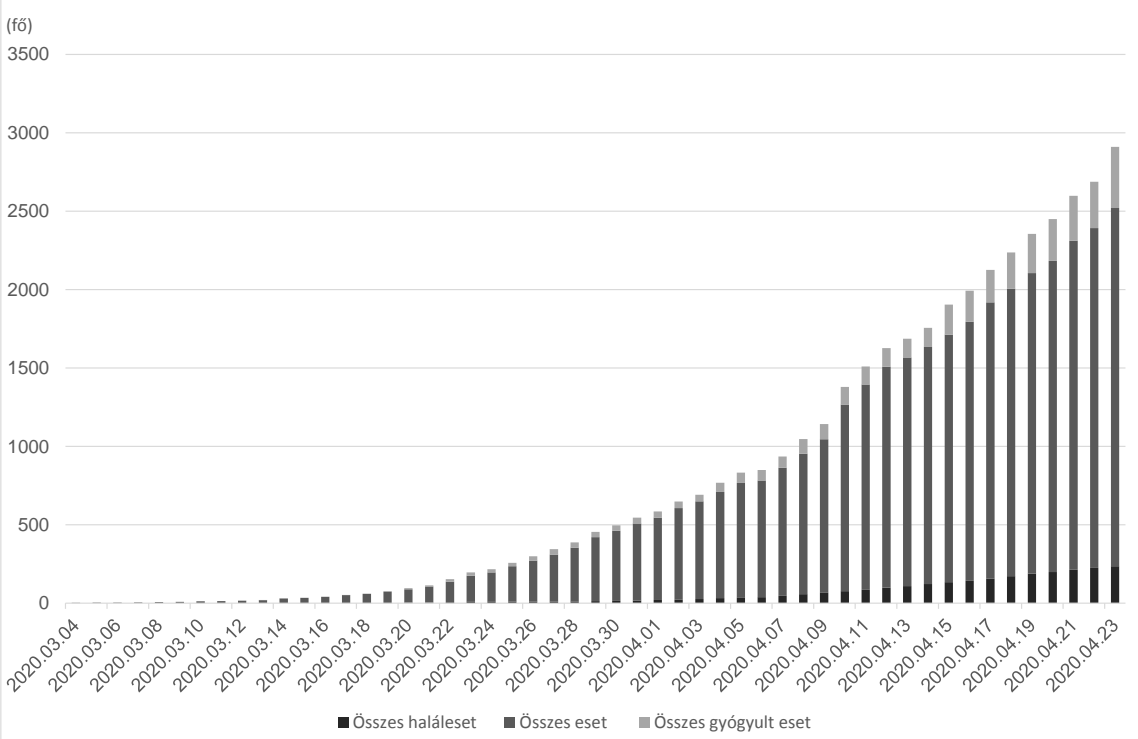

Adatok forrása: koronavirus.gov.hu 
3. ábra: Az új koronavírus okozta halálesetek megoszlása nemek és korcsoportok szerint Magyarországon (fö), 2020. 04. 23.

Mortality rate of COVID-19 pandemic by gender and age in Hungary (cases), 23. 04. 2020.

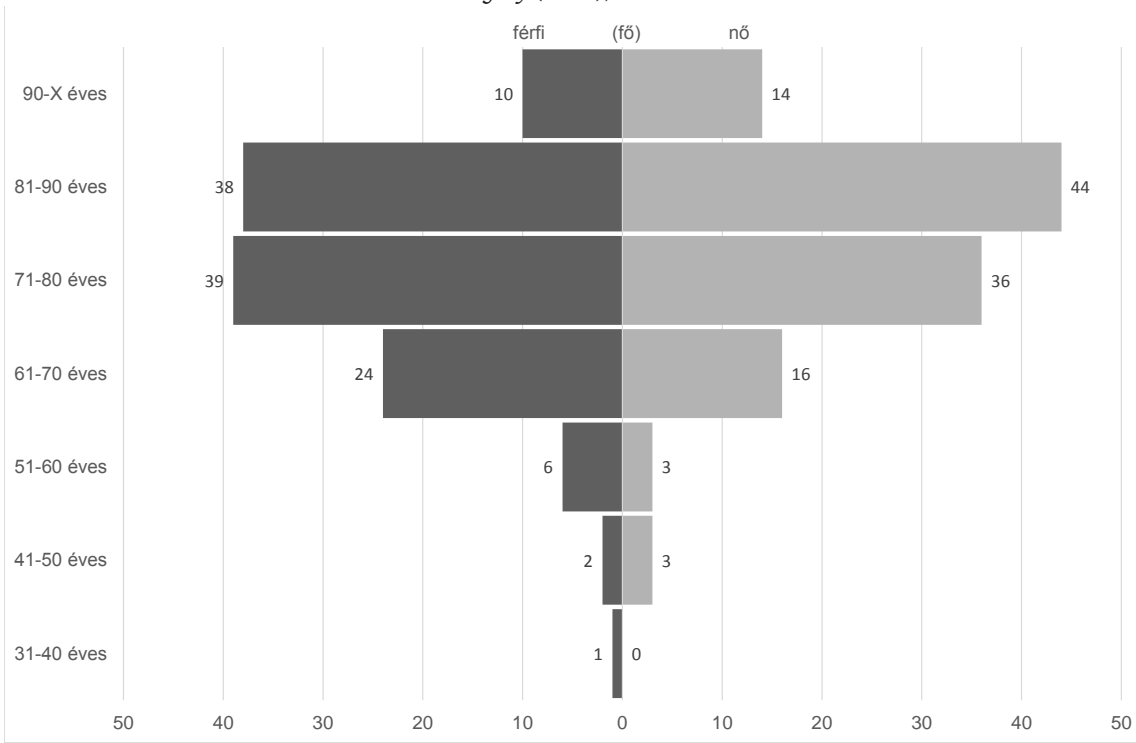

Adatok forrása: koronavirus.gov.hu

4. ábra: A koronavírus-fertőzés miatt elhunytak esetében az ismert alapbetegségek megoszlása Magyarországon (\%), 2020. 04. 23.

Distribution of comorbidity among deaths by COVID-19 pandemic in Hungary (\%), 23. 04. 2020.

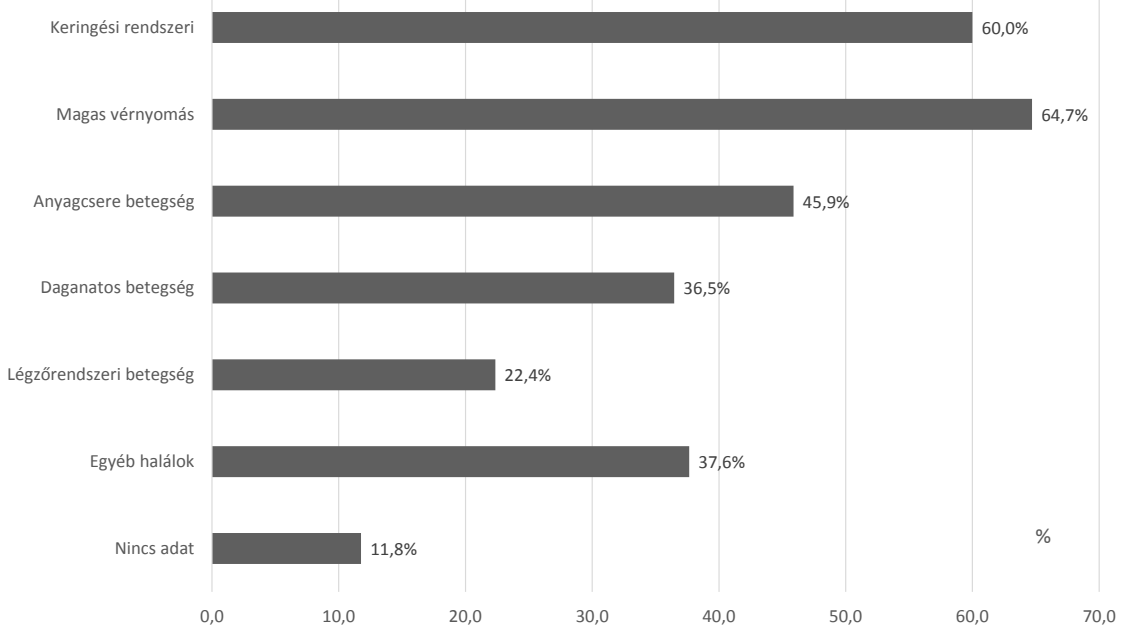

Adatok forrása: koronavirus.gov.hu 
Az elhunytak átlagéletkora 78,8 év volt: ez a nőknél 79,1 év, férfiaknál 78,5 év. A legtöbb halálozás főként a 81-90 év közötti nőket, és a 71-80, illetve 81-90 év közötti férfiakat érintette (3. ábra). A halálozások több, mint 80\%-a a 65 év felettieket érintette.

Az elhunytak alapbetegségei általában az időskori krónikus, idült, degeneratív betegségekből adódtak (4. ábra). A legtöbb esetben a koronavírus-fertőzés mint halálok mellett egyéb két-három társbetegség is jelen volt az áldozatoknál. Többségük keringési rendszeri betegségekre (például szívelégtelenség), magas vérnyomásra, anyagcsere-rendellenességekre (például cukorbetegség), légzőrendszeri betegségekre (például krónikus obstruktív tüdőbetegség) vezethető vissza.

Az igazoltan COVID-19 új koronavírussal fertőzöttek megyei megoszlása - a járvány 2020. április 13-19. közötti hetében - felhívja a figyelmet az országosan magas esetszámokra Budapesten, Pest és Fejér megyében, illetve az ország (egyelőre) nyugat-keleti megosztottságára (5. ábra). Az összes fertőzött 100000 főre vetített értéke alapján a járvány első hat hetében Kelet-Magyarország kevésbé volt érintve, az új esetszámok is alacsonyak voltak (kivéve Csongrád megye).

5. ábra: Az igazoltan COVID-19 új koronavírussal fertőzöttek száma összesen Magyarországon a megyékben (fö), 2020. 04. 13. - 04. 19. All cases of COVID-19 pandemic in Hungary at county level, between 13. 04. 2020. and 19. 04. 2020.

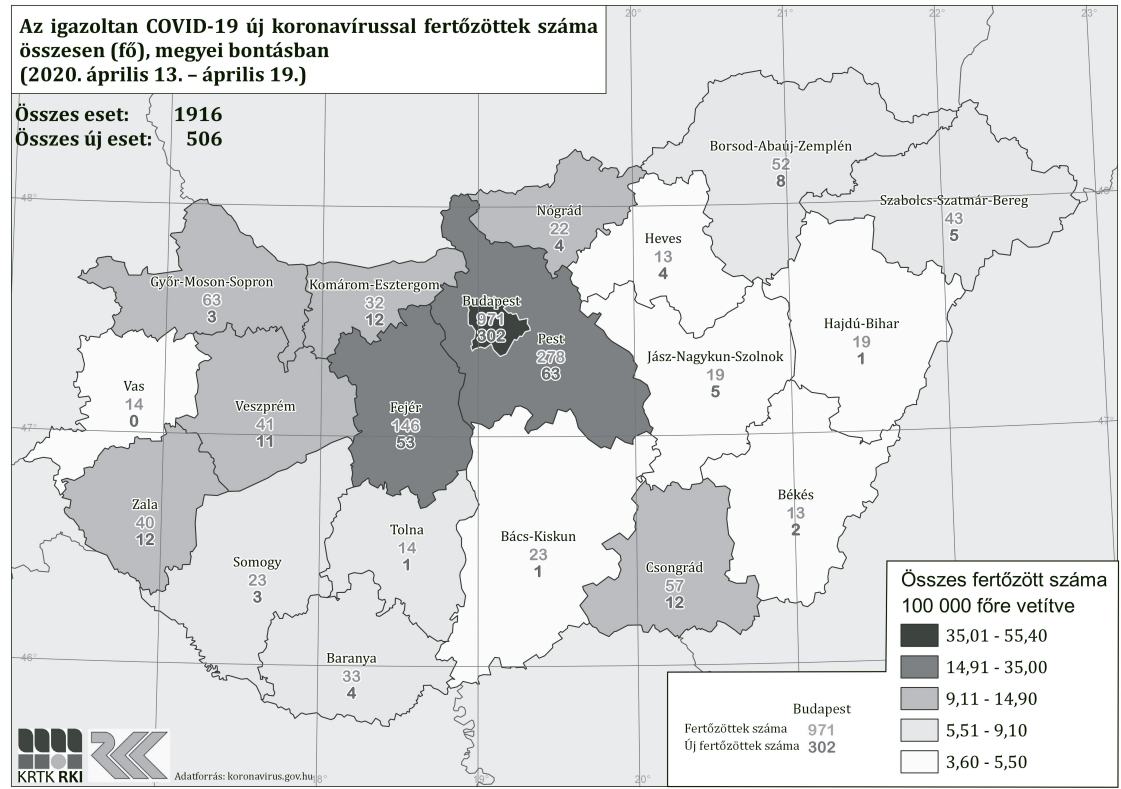

Adatok forrása: http://www.rkk.hu/hu/aktualitasok/a-koronavirus-jarvany-teruleti-adatai.html 


\section{Egészségkockázatok a járvány idején - Mely területek a leginkább veszélyeztetettek?}

Az új koronavírus járvány legveszélyeztetettebb csoportjai az idősek - elsősorban a 65 év felettiek -, valamint a krónikus betegségekben - magas vérnyomás, szívbetegség, tüdőbetegség, anyagcserezavar stb. - szenvedők. Körükben nagyobb az esély a fertőzés súlyosabb, életveszélyes lefolyására, a komplikált esetek kialakulására, a szövődmények miatt hosszabb kórházi kezelésre, és magasabb a fertőzés okozta halálozási kockázat is.

Különösen fontos figyelemmel kísérni a járvány alakulását és lefutását azokon a területeken, ahol országosan kedvezőtlen a helyi népesség egészségi állapota, vagyis rosszabbak az életkilátások, magasabb a krónikus (keringési rendszeri és daganatos) betegek aránya (6-9. ábrák). Az egészségi állapot szempontjából is hátrányos helyzetü területek, országrészek földrajzi elhelyezkedése egyrészt utal a kockázati csoportok (idősek, krónikus betegek) térbeli jelenlétére, másrészt jelzi azokat az egészségkockázatokat, amelyek befolyásolhatják a járvány súlyosabb eseteinek előfordulását és/vagy a koronavírus-fertőzés miatti nagyobb halálozási kockázatot.

6. ábra: A születéskor várható átlagos élettartam az országos átlaghoz viszonyítva

Magyarországon a járásokban, nők, 2013

Average life expectancy at birth compared to the national average in Hungary

at micro-regional level, female, 2013

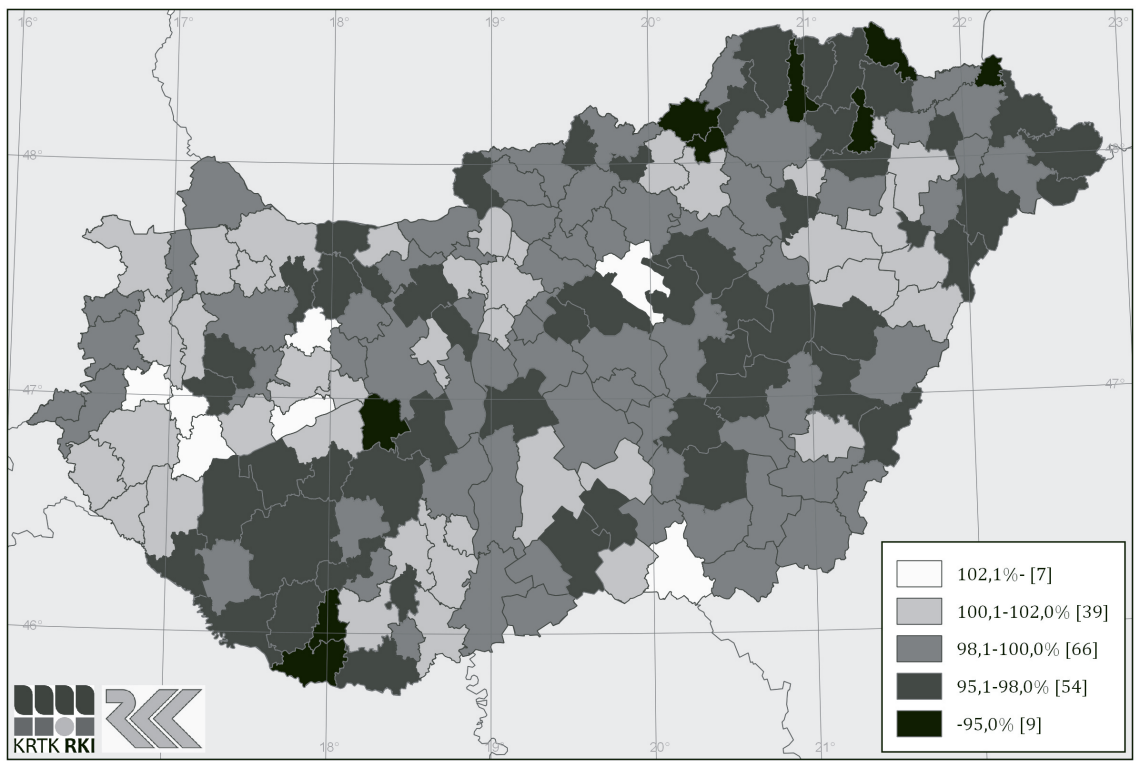

Adatok forrása: Központi Statisztikai Hivatal 
7. ábra: A születéskor várható átlagos élettartam az országos átlaghoz viszonyítva

Magyarországon a járásokban, férfiak, 2013

Average life expectancy at birth compared to the national average at in Hungary at micro-regional level, male, 2013

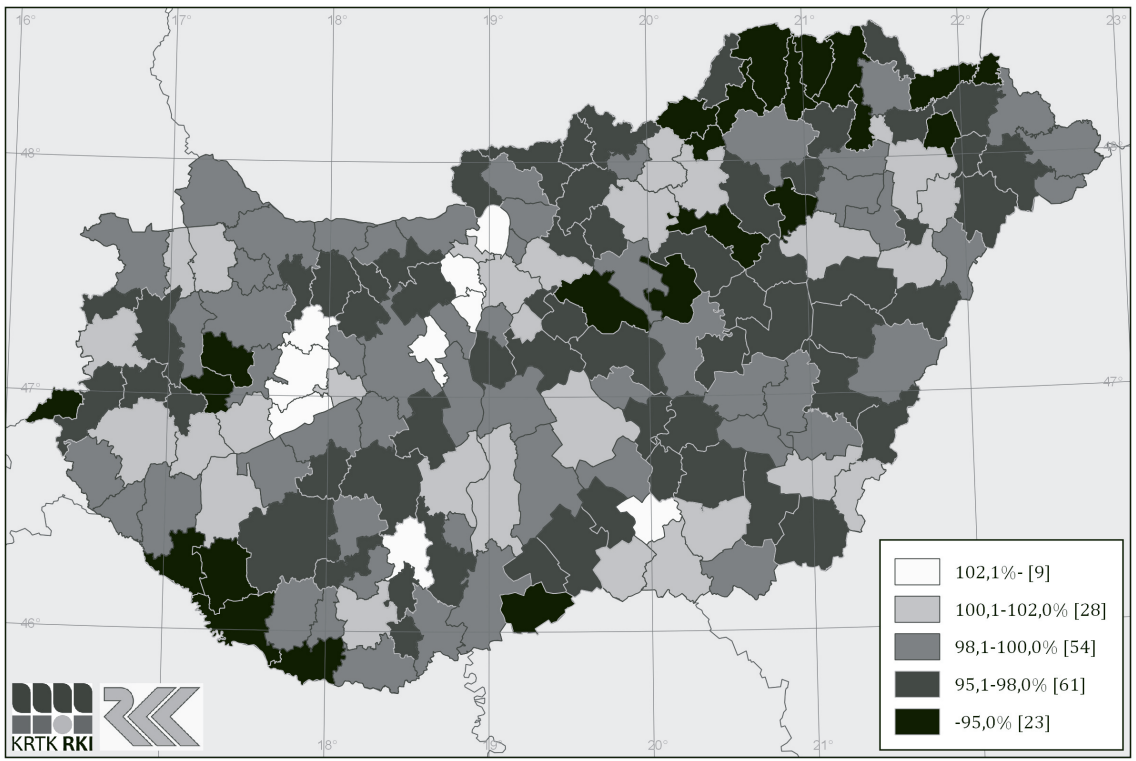

Adatok forrása: Központi Statisztikai Hivatal

Jelen dolgozat leadásának időpontjában (2020. 04. 23.) egyelőre nem látjuk pontosan a hazai koronavírus-járvány időbeli lefutását (tetőzését, lecsengését), de a különböző előreszámítások, járványstatisztikai modellek alapján feltételezhetjük, hogy Magyarországon májusban kell számítani a legtöbb fertőzöttre és napi új esetre. Ez alapján úgy látjuk, hogy elemzési eredményeink fontos információkkal szolgálhatnak az ellátásszervezés, kapacitástervezés és forrásallokáció területi optimalizálásához arról, hogy:

- Észak- és Kelet-, illetve Délnyugat-Magyarországon megyei szinten több olyan járványkórházat szükséges kijelölni, ahol rendelkezésre állnak a megfelelő kapacitások a súlyos fertőzött esetek ellátására. Ez abban az esetben is prioritás, ha a járvány kisebb fertőzött esetszámmal jár ezekben az országrészekben, de az egyéb meglévő egészségkockázatok miatt több súlyos, komplikált esetre lehet számítani. A járványkórházak kijelölése mellett azonban fontos, hogy megyei szinten a központi fekvésű, jól megközelíthető kórházakban tovább lehessen folytatni az akut és/vagy krónikus betegek ellátását.

- Az aprófalvas térségekben biztosítani kell az idősek és krónikus betegek izolációját, ellátásuk (élelmiszer, gyógyszer, hivatalos ügyek intézése) megszervezése az elkövetkező hetekben kiemelt feladat kell, hogy legyen 
8. ábra: Keringési rendszeri megbetegedések 1000 főre Magyarországon a járásokban, 2015 Morbidity rate of circulatory system per 1.000 in Hungary at micro-regional level, 2015

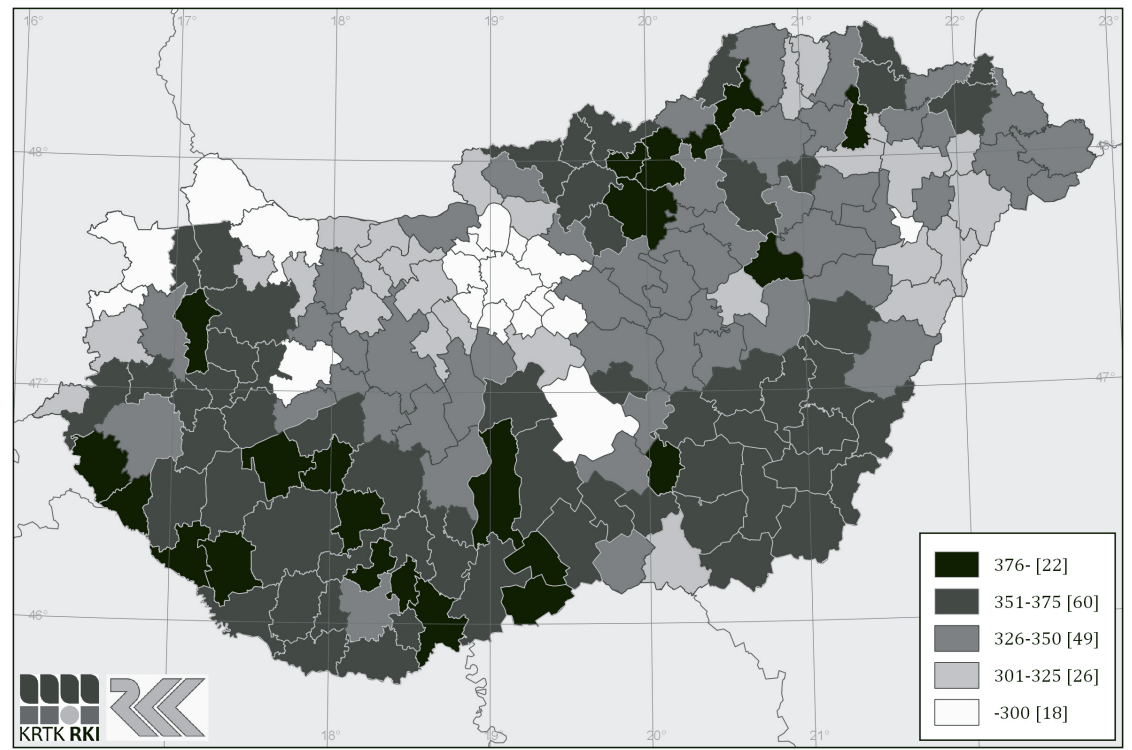

Adatok forrása: Központi Statisztikai Hivatal

9. ábra: Daganatos megbetegedések 1000 före Magyarországon a járásokban, 2015 Morbidity rate of circulatory system per 1.000 in Hungary at micro-regional level, 2015

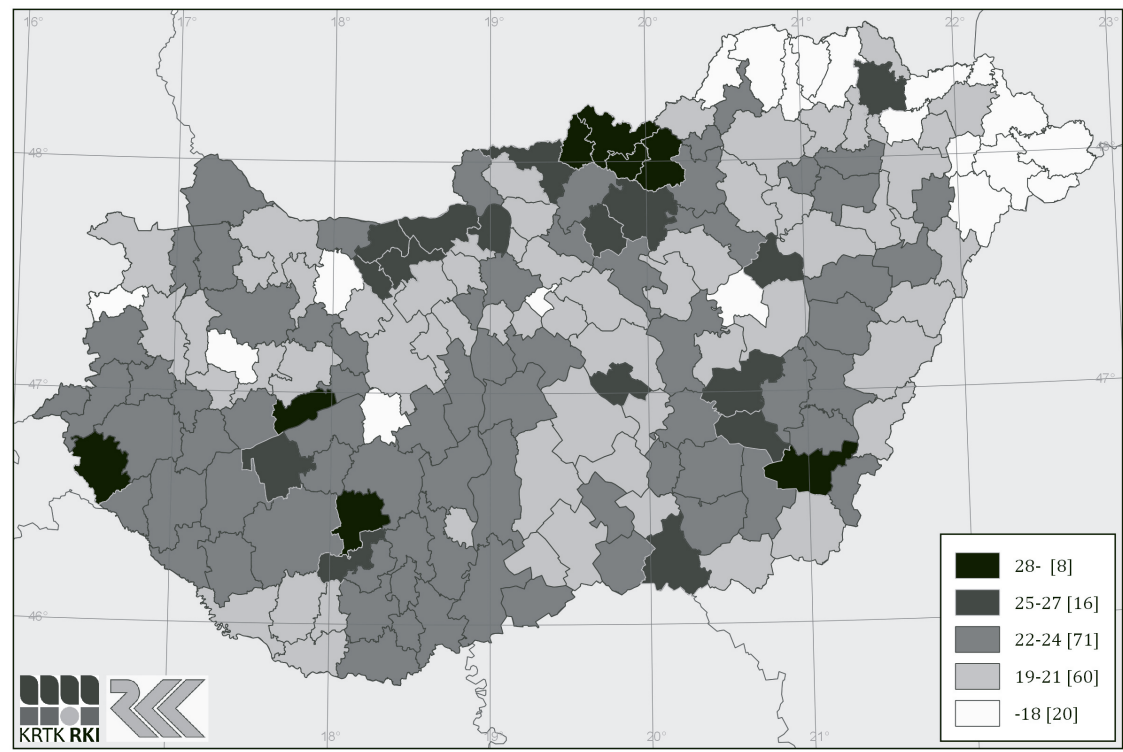

Adatok forrása: Központi Statisztikai Hivatal 
a helyi önkormányzatok és szociális intézmények számára, minél nagyobb számban bevonva a civil szervezeteket.

- A hátrányos helyzetü területeken a sérülékeny társadalmi csoportok körében a felvilágosítás, a megelőzés és a szűrés feladatait integráltan koordinálhatja a háziorvosi, a védőnői és a szociális ellátás.

\section{A járvány „rejtett” betegei - Hogyan csökkenthetjük a jövőbeli elkerülhető halálozást?}

A vizsgálatokban alkalmazott komplex egészségügyi távolság index összetett információhordozó adott területegység társadalmi és gazdasági helyzetéről, a népesség egészségi állapotáról és az egészségügyi intézmények elérhetőségéről, hozzáférhetőségéről (lásd a Függelék módszertani leírását). Az index magas értékei a társadalmi-gazdasági hátrányokra, az időskorúak magasabb arányára, a kedvezőtlenebb egészségi állapotra, az egészségügyi intézmények elérhetőségének és hozzáférhetőségének akadályaira utalnak.

Az alkalmazott komplex index alapján legrosszabb helyzetben lévő járások elsősorban a belső és a földrajzi perifériákon (határ menti területeken) helyezkednek el. A 10. ábrán kirajzolódik a megyeszékhelyek járásainak jobb helyzete, amely elsősorban az egészségügyi intézmények megyei szinten központi elhe-

10. ábra: Komplex egészségügyi távolság index Magyarországon a járásokban, 2018 Complex Health Distance Index in Hungary at micro-regional level, 2018

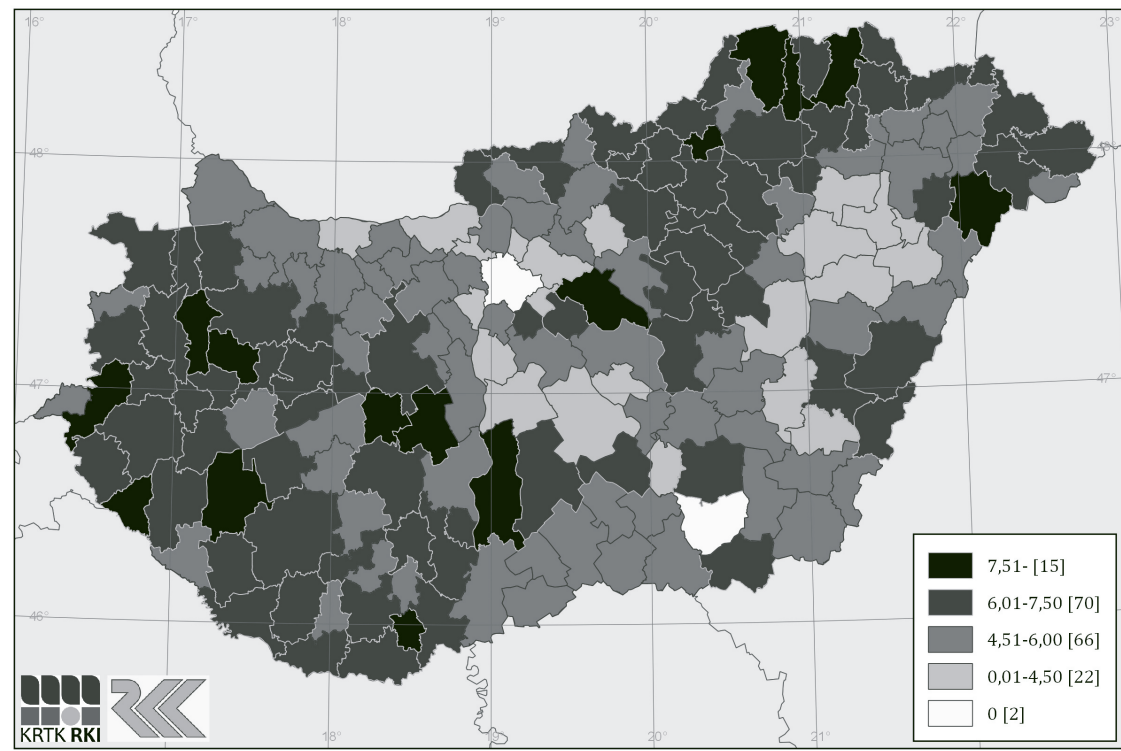

Adatok forrása: Központi Statisztikai Hivatal, Nemzeti Egészségbiztosítási Alapkezelő, Nemzeti Választási Iroda 
lyezkedésére, és így a kedvezőbb elérhetőségre utal. A budapesti agglomeráció előnyös helyzete a fóvárosban található egészségügyi intézmények jobb elérhetöségéből, hozzáférhetőségéből fakad. Érdekes a Hódmezővásárhelyi járás, ahol minden településén (4) található járóbeteg-ellátóközpont, így a kumulált járási indexérték 0. A komplex egészségügyi távolság index legmagasabb értékekeit azaz a rosszabb egészségi és egészségügyi helyzetet - ott tapasztaljuk, ahol a járásban nincs, vagy csak a járásszékhelyen van járóbeteg-szakrendelő (például a Letenyei, Nagykátai, Nyírbátori, Gönci járás). Az alföldi járások alacsonyabb településszáma miatt jobbak a fizikai elérhetőség mutatói, így ezek a területek kedvezőbb képet mutatnak a Dunántúllal összehasonlítva. Általában megállapítható, hogy a megyeszékhelyjárások közvetlen közelében magas értékek tapasztalhatók. Ennek oka az lehet, hogy a megyeszékhely viszonylagos fizikai közelsége miatt nincs, vagy kevés járóbeteg-szakrendelő van a szomszédos járásokban. Ugyanakkor a megyeszékhely járása és a szomszédos járások között számottevő a különbség a többi vizsgált (társadalmi, gazdasági, egészségi) mutató alapján.

A jelenlegi járványügyi veszélyhelyzet miatt lényegében országszerte szünetelnek a kivizsgálások, a krónikus betegségek szürései, a halasztható műtétek, drasztikusan lecsökkent az orvos-beteg találkozások száma, és csak az akut, életveszélyes és sürgősségi esetek ellátása zajlik. A kijárási korlátozások miatt az emberek többsége - a koronavírus-fertőzéstől való félelem miatt is - igyekszik elkerülni az egészségügyi ellátás igénybevételét. Ez már középtávon átalakítja az egészségügyi ellátórendszert, mert:

- kapacitáshiányok léphetnek fel, egyrészt a 65 év feletti orvosok kivonásával a közvetlen ellátásból (csak háttérfeladatokat láthatnak el), másrészt az egészségügyi szakdolgozók megbetegedésével;

- felerősödik a telemedicina használata (például távkonzultációkkal);

- felértékelődik az otthoni ápolás szerepe (például az ágykapacitások felszabadítása után hazaengedett nem fertőzött betegek számára);

- nőhet a járvány idején is engedélyezett magánellátás igénybevétele (például ügyeleti ellátásban).

A járvány idején - kényszerűen - elmaradt orvosi beavatkozások és szünetelő szolgáltatások rontják az egészségügyi ellátáshoz való hozzáférés esélyeit, és már középtávon súlyos egészségkárosodáshoz, hosszútávon elkerülhető halálozáshoz vezethetnek. A legtöbb krónikus betegség rendszeres orvosi kontrollt követel meg, de ez jelenleg az alap- és szakellátás szintjén nem valósul meg, vagy teljesen lelassult, megnehezedett. Az elmaradó rehabilitáció a későbbiekben súlyos, maradandó károsodásokat okozhat. A szürővizsgálatok hiányában számos daganatos betegség diagnózisa elmarad vagy később történik meg, csökkentve a túlélési esélyeket. A bizonytalanság, a bezártság, a fertőzéstől és egyéb betegségektől való félelem szorongással és depressziós tünetegyüttes kialakulásával járhat, orvosi felismerés és kezelés hiányában pedig már rövid időn belül különböző pszichoszomatikus betegségekhez vezethet. 
A fent vázolt, nem járványügyi, de a járványhoz kötődő ,járulékos tünetegyüttes" a COVID-19 járvány következménye, és elsősorban azokat a betegeket sújtja, akik az egyéb, nem koronavírushoz köthető betegségük ellátásában, gondozásában, gyógykezelésében, szűrésében és diagnózisában akadályozva vannak, a járvány idején ellátatlanok, és csak késve kapják meg az ellátást, vagyis az ellátórendszer számára egyelőre rejtve maradnak. Számukra különösen fontos lesz a járvány elmúltával az ellátáshoz való hozzáférés biztosítása, de ez kivált azokon a területen járhat együtt akadályokkal, ahol sok a betöltetlen háziorvosi praxis, és ezek területileg koncentráltan helyezkednek el (11. ábra).

Jelen elemzés elkészítésének időpontjában (2020. 04. 23.) még nem állnak rendelkezésre statisztikai adatok a magyar népesség 2020. és 2021. évi megbetegedési és halálozási helyzetéről, de az egészségi állapot és az egészségügyi ellátórendszer meglévő területi különbségei alapján feltételezzük, hogy a koronavírus-járvány következtében a jövőben egyes országrészekben és társadalmi csoportoknál egészségromlás következhet be. Eredményeink hasznosak lehetnek az ellátásszervezés számára arról, hogy a térbeli igazságosság, méltányosság elve hogyan érvényesíthető az egészségügyi ellátáshoz való hozzáférés biztosításában mind a járvány idején, mind a jövőben:

- A háziorvosi ügyeleti rendszer területi megerősítése: azokon a területeken, ahol sok a betöltetlen háziorvosi szolgálat (például Borsod-Abaúj-Zemplén, Pest, Jász-Nagykun-Szolnok megye) különösen fontos a

11. ábra: A betöltetlen háziorvosi szolgálatok aránya Magyarországon a járásokban, 2019 Rate of vacant General Practitioner services in Hungary at micro-regional level, 2019

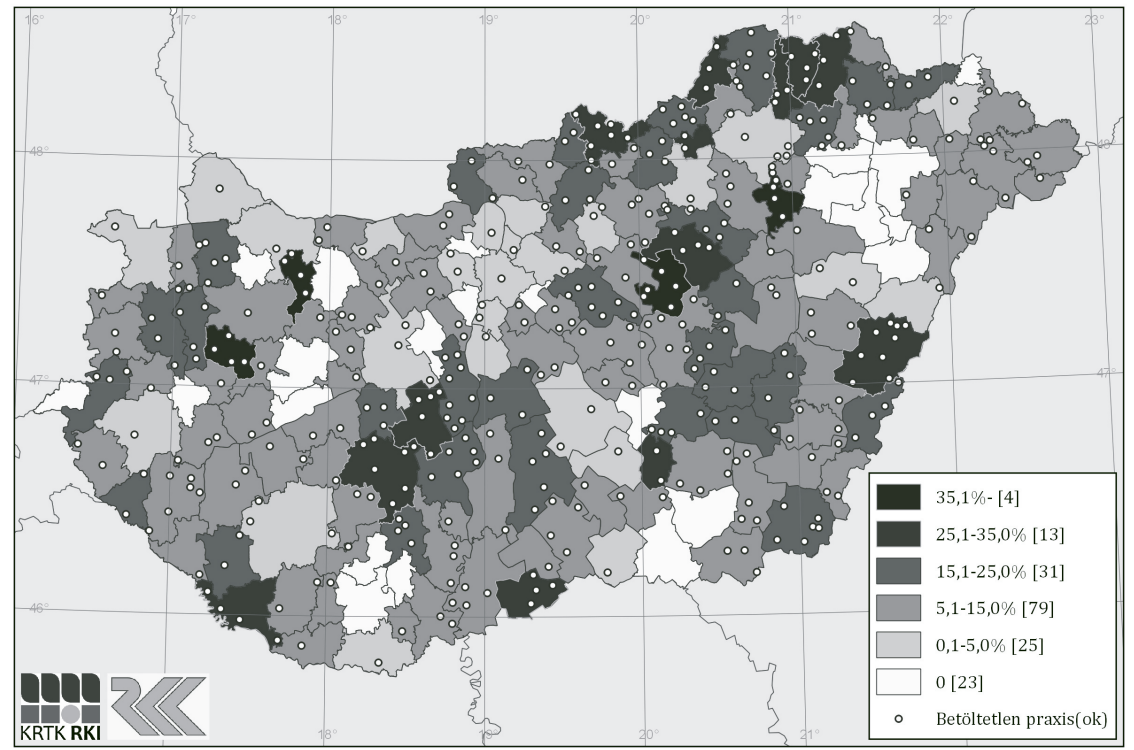

Adatok forrása: Nemzeti Egészségbiztosítási Alapkezelo" 
háziorvosi ellátás megerősítése az ügyeleti rendszeren keresztül járvány idején is.

- Betegellátó központok területi koncentrálása járvány idején: legalább a megyeszékhelyen biztosítani szükséges a járóbeteg-szakellátás egyes szakmáinak járvány idején is biztonságos fenntartását, illetve a mobilizálható és / vagy távkapcsolatban működtethető egészségügyi szakszolgálatokat, főként a belső és földrajzi perifériákon, határ menti országrészekben, megyeszékhelyektől távoli területeken. Ezeken a hátrányos helyzetű területeken a járvány után különösen fontos lesz a krónikus betegségek szürése és az ellátatlan betegek hozzáférésének biztosítása.

- A legnagyobb egészségnyereség területi optimalizálása: populációs szinten és országszerte az egészségügyi kapacitások átcsoportosításával rendszeressé lehetne tenni a krónikus betegségek szürését és gondozását a járvány idején is.

\section{Összefoglalás}

Az új típusú koronavírus megbetegedések és halálozások okozta járvány komoly hatással lesz a társadalom és a gazdaság minden területére. Az egészségügyi ellátórendszert és a népegészségügyi helyzetet tekintve is komplex hatásokra kell számítani, és ez várhatóan az egészségegyenlőtlenségek átrendeződésével, részben új típusú egyenlőtlenségek kialakulásával jár majd együtt. Mindezek térbeli-területi következményei komplex módon fognak jelentkezni nemzeti és lokális szinten egyaránt, és ezek az egészségügyi ellátórendszer működtetésében és a népegészségügyi helyzet fenntartásában eredményeznek kihívásokat. Az egészségügyi ellátáshoz való hozzáférés feltételei átalakulnak a járvány idején, lényegében mindenki számára beszűkülnek a lehetőségek, de a leghátrányosabb helyzetű csoportok egészségveszteségei lesznek a legnagyobbak.

A gyors, megfelelő, több szektort is érintő intézkedések fontos részét képezhetik a következmények enyhítésének és a jövőbeli hasonló helyzetekre való eredményes felkészülésnek. A világjárvány egészségi állapotra és egészségügyre gyakorolt hatásai számos további kutatási kérdést felvetnek. Milyen területi mintázatok jellemzőek az új típusú koronavírus megbetegedések és halálozások térbeli eloszlására? Hogyan hat az emberi viselkedés (egészségmagatartás) a fertőző betegségek terjedésére, és ez milyen szakpolitikai eszközökkel befolyásolható? A nemzeti járványügyi veszélyhelyzet milyen mechanizmusokon keresztül gyakorol hatást az egészségügyi ellátás igénybevehetőségére és a hozzáférés feltételeire? Hogyan alakulnak az egészségi állapotban tapasztalható társadalmi-területi egyenlőtlenségek a világjárvány hatására? Melyek a hatékony egészségügyi beavatkozások a járvány vissza- 
szorításában, és ezek milyen jó gyakorlatokat jelenthetnek az ellátásszervezés optimalizálásában?

Jelen elemzés legfontosabb következtetései alapján úgy látjuk, hogy a világjárvány hazai következményeinek enyhítésében prioritást kell kapnia az ellátásszervezés szükségletalapú aktualizálásának, valamint területi alapú optimalizálásának.

\section{Jegyzetek}

1 A kézirat lezárásának időpontja: 2020. április 23.

2 A kézirat korábbi változata mint a KRTK Regionális Kutatások Intézete koronavírussal összefüggő műhelytanulmánya Egészségkockázatok területi különbségei a koronavírus-járvánnyal összefüggésben Magyarországon címmel jelent meg, elérhetősége: http://www.docs.rkk.hu/rkkweb/ Koronavirus_jarvany_gyorselemzes.pdf

\section{Irodalom}

Alessandrini, P., Presbitero, A. F., Zazzaro, A. (2009): Banks, Distances and Firms' Financing Constraints. Review of Finance, 2., 261-300. https://doi.org/10.1093/rof/rfn010

Dahlgren, G., Whitehead, M. (1991): Policies and strategies to promote social equity in health. Institute of Futures Studies, Stockholm

Kovács, S. Zs. (2018): Dualities of the Hungarian Credit Institute Activities. Deturope: The Central European Journal of Regional Development and Tourism, 3., 108-119.

McIntyre, D., Thiede, M., Birch, S. (2009): Access as a policy-relevant concept in low-and middle-income countries. Health Economics, Policy and Law, 4., 179-193. https://doi.org/10.1017/S1744133109004836

Uzzoli A., (2019): Health inequalities in Hungary - Challenges for health care system. Society, Economics, Law Conference. In: Karlovitz, T. (ed.): People and their values in the society. Sozial und Wirtschafts Forschungsgruppe, Grosspetersdorf, 129-138.

\section{Internetes források}

koronavirus.gov.hu (Letöltés: 2020. április 23.)

https://www.teir.hu/ (Letöltés: 2020. április 03.)

www.ksh.hu (Letöltés: 2020. április 04.)

https://www.valasztas.hu/ (Letöltés: 2020. április 04.)

http://www.oep.hu/ (Letöltés: 2020. április 07.)

http://www.rkk.hu/hu/aktualitasok/a-koronavirus-jarvany-teruleti-adatai.html (Letöltés: 2020. április 23.)

http://statinfo.ksh.hu/Statinfo/themeSelector.jsp (Letöltés: 2020. április 04.) 


\section{Függelék}

A Komplex Egészségügyi Távolság Index / Complex Health Distance Index (CHDI) számítási módszertana

Települési lépték

$\mathrm{CHI}_{i}=\mathrm{PD}_{i}+\mathrm{SD}_{i}+\mathrm{ED}_{i}+\mathrm{D} 1$

Ahol:

Komponens 1: Fizikai távolság a vizsgált település és a legközelebbi járóbeteg ellátó intézmény között

$P D_{i}=\operatorname{In}\left(1+K M_{i j}\right)$, ahol

$P D_{i}$ - a komponens értéke

$K M_{i j}$ - a két település közötti km-ben kifejezett távolság

Komponens 2: Társadalmi különbségek

$S D_{i}=\sum_{m=1}^{n} \ln \left(1+\left|S C_{m i}-S C_{m j}\right|\right)$, ahol

$S D_{i}$ - a komponens értéke

$S C_{m}$ - a vizsgált társadalmi mutató értéke

$m$ - vizsgált társadalmi mutatószám (jelenleg: 1 . öregedési index; 2. munkanélküliség; 3. választási részvétel, 4. születéskor várható átlagos élettartam, 5. nyers halálozási arányszám, 7. keringési és daganatos betegségek volumene)

Komponens 3: Gazdasági/fejlettségi eltérések

$E D_{i}=\sum_{k=1}^{l} \ln \left(1+\left|E C_{k i}-E C_{k j}\right|\right)$, ahol

$E D_{i}$ - a komponens értéke

$E C_{m}$ - a vizsgált gazdasági mutató értéke

$m$ - vizsgált gazdasági elem (jelenleg: 1 . munkaerő szektorális eloszlása; 2 . vállalkozások szektorális összetétele; 3 . internetkapcsolatok volumene)

Dummy változó 1 .

0 - betöltetlen háziorvosi praxisok aránya kisebb 20\%

1 - betöltetlen háziorvosi praxisok aránya nagyobb $20 \%$

Nagyobb területi léptékre adaptálás

$$
\text { CHDI }_{J}^{*}=\frac{\sum_{i=1}^{m} \text { Lakosságszám }_{i} * C_{H D I_{i}}}{\text { Teljes lakosságszám }}
$$

